\title{
Relationships between size, mantle area and zooxanthellae numbers in five species of giant clam (Tridacnidae)
}

\author{
C. L. Griffiths ${ }^{1, *}$, D. W. Klumpp ${ }^{2}$ \\ ${ }^{1}$ Zoology Department, University of Cape Town, Rondebosch 7700, South Africa \\ ${ }^{2}$ Australian Institute of Marine Science, PMB No 3, Townsville MC, Australia 4810
}

\begin{abstract}
Relationships between body size and both projected mantle area and numbers of symbiotic zooxanthellae were calculated for 5 species of giant clam from the Great Barrier Reef. Parameters were closely correlated in all species, but the allometry of the relationships differed markedly between clam species. Mantle areas were consistently lowest in Tridacna derasa. T crocea and Hippopus hippopus had the largest mantles at small body size $(2 \mathrm{~cm})$, but because of slow length-related increments were soon overtaken by $T$ gigas and $T$ squamosa, the latter developing a mantle area double that of other species at $30 \mathrm{~cm}$ length. Similar allometric variations were evident in zooxanthellae numbers. At small size these were much lower in $T$. squamosa and $T$. gigas than in $H$. hippopus, $T$. crocea or especially $T$ derasa; but by $30 \mathrm{~cm}$ length $T$. squamosa and $T$ gigas had the largest zooxanthellae populations. When expressed per unit body mass zooxanthellae numbers declined rapidly with size in all species. The rate of decline was most marked in $T$ crocea, this being a function of its rapid length-related increment in flesh mass. This is probably the main factor restricting $T$ crocea to small terminal body size. By contrast, rapid length-related increments in mantle area and zooxanthellae numbers in both $T$. gigas and $T$. squamosa appear to favour the large body size and rapid growth observed in these species. The reason why $T$ squamosa is unable to realize the rapid growth and enormous terminal size observed in $T$. gigas is obscure, but may be a function of the relative reproductive output of these species, which remains unquantified.
\end{abstract}

KEY WORDS: Giant clam - Tridacna Hippopus Symbiosis $\cdot$ Zooxanthellae

\section{INTRODUCTION}

Giant clams of the family Tridacnidae are familiar and conspicuous residents of shallow coral reefs throughout much of the tropical Indo-Pacific. Their most characteristic feature is the enlarged, upwardly directed and usually brightly coloured mantle, which is packed with symbiotic dinoflagellate zooxanthellae. An estimated $95 \%$ of the carbon fixed by these algal symbionts is translocated to the host (Fitt 1993, Klumpp \& Griffiths 1994), where it normally provides sufficient energy to cover at least the immediate metabolic needs of the hosts (Tench et al. 1981, Fisher et al. 1985, Minกูก 1988, Klumpn \& Griffiths 1994, Klumpp \& Iucas

\footnotetext{
•E-mail: clgriff@ucthpx.uct.ac.za
}

1994). Giant clams are also able to filter food particles from the water column (Yonge 1936), although the nutritional significance of this has only recently been quantified. Fitt et al. (1986) first quantified ingestion and digestion of $\mathrm{C}^{14}$-labelled phytoplankton cells by Tridacna gigas, while Klumpp et al. (1992) showed that particulate food constituted $65 \%$ of carbon needs in small ( $0.1 \mathrm{~g}$ dry tissue) $T$. gigas, declining to $34 \%$ in individuals of $10 \mathrm{~g}$ weight. This capacity to exploit both heterotrophic and autotrophic sources of nutrition, plus an ability to divert an unusually high proportion of energy into growth (Klumpp et al. 1992), are no doubt factors that have allowed $T$. gigas to become the largest $(137 \mathrm{~cm},>500 \mathrm{~kg})$ and fastest groxing ( $>100$ $\mathrm{mm} \mathrm{yr}^{-1}$ ) bivalve ever to have existed.

Not all tridacnid clams, however, attain these impressive dimensions-indeed the 9 described species 
differ greatly in both growth rate and terminal size, as well as in the range of coral reef habitats they colonize (Lucas 1988). Thus, Tridacna gigas attains a weight an order of magnitude heavier than that of any other species, while $T$. crocea is by far the smallest form, reaching a shell length of only $15 \mathrm{~cm}$. Habitat preferences also vary from the intensely lit waters of intertidal reef flats (Hippopus hippopus, T. crocea) to depths as great as $33 \mathrm{~m}$ in the recently discovered $T$. tevoroa (Ledua et al. 1993).

Two recent studies have attempted to compare the rates of energy aquisition in the various species of giant clam and to correlate these with their habitat preferences and growth performance. Klumpp \& Lucas (1994) showed that Tridacna tevoroa and $T$. derasa from Tonga function identically in shallow water, but that $T$. tevoroa is able to maintain its photosynthetic capacities at lower light intensities, explaining its ability to maintain a positive energy balance in the deeper waters in which most of the remaining population is found (Ledua et al. 1993). Klumpp \& Griffiths (1994) used a similar protocol to compare rates of energy aquisition and expenditure in 4 species of giant clam from the Great Barrier Reef. Their results demonstrate that small (0.1 g dry flesh mass) $T$. gigas not only filter feed at more than 10 times the rate of the remaining species, but photosynthetically fix energy at twice the rate shown in $T$. crocea, 4 times that in $T$. squamosa and 20 times that in $H$. hippopus of equivalent weight. These rates, however, converge with increasing clam size, to differ by less than 2-fold by a weight of $100 \mathrm{~g}$ dry flesh mass.

To date the mechanisms underlying these marked size-related changes in photosynthetic rate are unknown. In this paper we make a first attempt at investigating the basis for these differences by examining allometric changes in both mantle area and zooxanthellae population size in 5 of the species for which photosynthetic data are available. It is hoped that these data will provide some insight into why giant clams show such different size-related photosynthetic rates, and hence such a wide range of growth rates and terminal sizes.

\section{METHODS}

Collection and maintenance of clams. The Tridacna gigas used in this study were cultured specimens obtained from the mariculture facility on Orpheus Island $\left(18^{\circ} 37^{\prime} \mathrm{S}, 146^{\circ} 30^{\prime} \mathrm{E}\right)$ in North Queensland, Australia. Hippopus hippopus and T. crocea were collected from intertidal fringing reefs at Iris Point and Pioneer Bay, also on Orpheus Island, respectively. $T$. squamosa were taken at depths of 1 to $10 \mathrm{~m}$ in the lagoon and from the reef flat of Davies Reef $\left(18^{\circ} 50^{\prime} \mathrm{S}\right.$, $147^{\circ} 38^{\prime} \mathrm{E}$ ) on the Great Barrier Reef and $T$. derasa from the nearby Bowl Reef. All clams were transferred to outdoor $2 \times 1 \mathrm{~m}, 0.5 \mathrm{~m}$ deep tanks at the Australian Institute of Marine Science. These tanks were roofed with $50 \%$ shadecloth and supplied with flow-through natural sea water at 24 to $27^{\circ} \mathrm{C}$. Clams were acclimated for a minimum of $3 \mathrm{wk}$ (and in most cases for several months) in these tanks before use in any experiments.

Mantle areas. Two-dimensional projections of mantle surface areas were computed from $35 \mathrm{~mm}$ colour slides shot from directly above each clam, using either a standard $35 \mathrm{~mm}$ SLR camera, or in the case of smaller clams, a Nikonos-V underwater camera fitted with Nikonos close-up kit and SB 103 flash. In an attempt to standardize degree of mantle expansion, all photographs were taken between 10:00 and 16:00 $\mathrm{h}$ on cloudless days. A $30 \mathrm{~cm}$ rule was positioned adjacent to each specimen (and at mantle height) to indicate scale. Clams were left for several hours to gape and expand the mantle fully following any disturbance betore being photographed. Some supplementary photographs of large $(>40 \mathrm{~cm}$ ) clams, especially Tridacna gigas, were also taken on clear sunny days and in water depths not exceeding $12 \mathrm{~m}$ at Bowl, Centipede and Davies Reefs using a Nikonos- $V$ with standard 35 mm lens and SB-103 flash. Between 17 and 27 specimens of each species, selected to cover as wide a size range as possible (see Fig. 1), were photographed.

Mantle areas were digitized using a Sonic- 8 digitizer and projected areas calculated using the trapezoidal algorithm for calculating areas from an irregular polygon.

Extraction and enumeration of zooxanthellae. The shell valves of clams used for zooxanthellae counts were jammed apart with wooden wedges and the adductor muscles pried free from the shell with a blunt knife. The mantle was then separated from the visceral mass and divided into left and right halves. The right mantle lobe and the visceral mass of each clam were cut into pieces, placed in separate foil dishes and dried to constant weight at $70^{\circ} \mathrm{C}$. Total dry mass was calculated from these values and regressed against shell length.

The left half of each mantle was cut into small pieces in a glass bowl, covered with filtered seawater and then homogenized in a kitchen blender. The homoginate was poured through a double layer of cheesecloth, resuspended in 2 further rinses of filtered seawater, then squeezed dry. The resulting suspension of zooxanthellae was made up to a known volume, which varied from 200 to $2000 \mathrm{ml}$, depending on clam size. A $1 \mathrm{ml}$ subsample from this concentrate was then diluted to $100 \mathrm{ml}$ and the zooxanthellae in $2 \mathrm{ml}$ of this suspen- 
sion counted using a model TA11 Coulter Counter with $140 \mu \mathrm{m}$ aperture tube. Two dilutions were made up from each clam and duplicate counts made from each. Total zooxanthellae numbers were back-calculated from the mean of these 4 counts.

Near the end of the experiment a more sophisticated Coulter Multisizer became available. This could resolve 256 size channels, relative to the 16 of the TA11 and allowed for a much clearer resolution of the sizefrequency peak representing the zooxanthellae. Samples from the last 10 clams were thus counted on both machines. The Multisizer counts so obtained were consistently $30 \%$ higher than those from the TA11. As a result all earlier counts made with the TA11 were corrected by a factor of 1.3 .

Zooxanthellae counts were not undertaken for Tridacna gigas, since measurements derived from the same clam population and using exactly the same extraction technique adopted here are available in Fitt et al. (1993).

Chlorophyll analysis. In order to determine whether zooxanthellae from the various clam species contained different amounts of chlorophyll, subsamples of $10 \mathrm{ml}$ zooxanthellae-concentrate from each clam were analysed for chlorophyll. Samples were filtered onto GF/C filter papers, which were then wrapped in foil and frozen in the dark for later analysis. Filters were subsequently homogenized in $90 \%$ acetone, transferred to a $10 \mathrm{ml}$ centrifuge tube for $2 \mathrm{~h}$ in total darkness, then centrifuged for $10 \mathrm{~min}$ at $3500 \mathrm{rpm}$. The absorbance of the supernatant was read at 630 and $663 \mathrm{~nm}$ and chlorophyll concentrations calculated according to the equations of Jeffrey \& Humphrey (1975).

No chlorophyll readings were taken for Tridacna gigas since measurements taken using similar techniques and based on the same population of clams are available in Belda et al. (1993).

Statistical methods. All statistics were carried out using the PC version of SAS version 6 , with the exception of multiple comparisons after analyses of covariance (ANCOVA), which were done manually, following Zar (1984).

Regression analyses were undertaken using the procedure 'REG' (one of several options for regression analysis in SAS), after appropriate transformations of the data had been carried out. ANCOVAs were done using the procedure for general linear models (GLM). Where the ANCOVA showed that slopes differed between species, no further analyses were done to determine differences between the means, but multiple comparison tests were carried out to determine pairwise differences between the slopes.
The differences in chlorophyll concentration per cell were tested between species using an ANOVA in the GLM procedure of SAS. The subsequent multiple comparison was done with the Ryan-Einot-Gabriel-Welsch multiple range test (SAS 1985).

\section{RESULTS}

\section{Mantle areas}

Projected mantle areas were closely correlated $\left(r^{2}>\right.$ 0.91) with shell length in all 5 of the clam species tested (Table 1, Fig. 1). Intercepts or a values (i.e. mantle areas at $1 \mathrm{~cm}$ length) differed significantly between species, ranging from a minimum of only $0.08 \mathrm{~cm}^{2}$ in Tridacna derasa to $0.31 \mathrm{~cm}^{2}$ in $T$. crocea. Slopes of the regression lines fell within the fairly narrow range 2.07 to 2.57 , with the slowest length-related increments in mantle area occurring in $T$. crocea and the fastest in $T$. squamosa.

All pairwise comparisons of slopes were significantly different except Hippopus hippopus against both Tridacna crocea and $T$. derasa.

Calculated mantle areas for clams of each species at standard lengths of 2,10 and $30 \mathrm{~cm}$ are also shown in Table 1 . The most noticeable feature of these results is the consistently small mantle area exhibited by Tridacna derasa. This is particularly evident in the larger size classes: mantle area at $30 \mathrm{~cm}$ shell length being only 18 to $47 \%$ of those of other species.

Relative trends in mantle area amongst the remaining species vary markedly with clam size. At small size Tridacna crocea has by far the largest mantle, followed by Hippopus hippopus. However, because of the relatively small length-related increments ( $b$ values) shown by both these species, they are soon overtaken by $T$. squamosa and subsequently $T$. gigas. Thus, by $30 \mathrm{~cm}$ length $H$. hippopus has a mantle area smaller than any other species except $T$. derasa. $T$. squamosa and $T$. gigas show the reverse trend, starting life with

Table 1 . Regression equations $\left(M A=a L^{b}\right)$ relating shell length $(L, c m)$ to projected mantle area $\left(\mathrm{MA}_{1} \mathrm{~cm}^{2}\right)$ in 5 species of giant clam. Also shown are the calculated mantle areas for clams of 2,10 and $30 \mathrm{~cm}$ length $(30 \mathrm{~cm}$ not attained by Tridacna crocea, hence parentheses around this value)

\begin{tabular}{|lcccccccc|}
\hline Species & $a$ & $b$ & $\mathrm{r}^{2}$ & $\mathrm{n}$ & \multicolumn{3}{c|}{ Area at length (cm) } \\
& & & & & 2 & 10 & 30 \\
\hline Hippopus hippopus & 0.211 & 2.139 & 0.91 & 24 & 0.93 & 29.1 & 304 \\
Tridacna crocea & 0.305 & 2.071 & 0.93 & 33 & 1.28 & 35.9 & $(349)$ \\
T. derasa & 0.0765 & 2.218 & 0.92 & 17 & 0.36 & 12.6 & 144 \\
T. gigas & 0.109 & 2.393 & 0.96 & 27 & 0.57 & 26.9 & 373 \\
T. squamosa & 0.130 & 2.569 & 0.97 & 21 & 0.77 & 48.2 & 810 \\
\hline
\end{tabular}



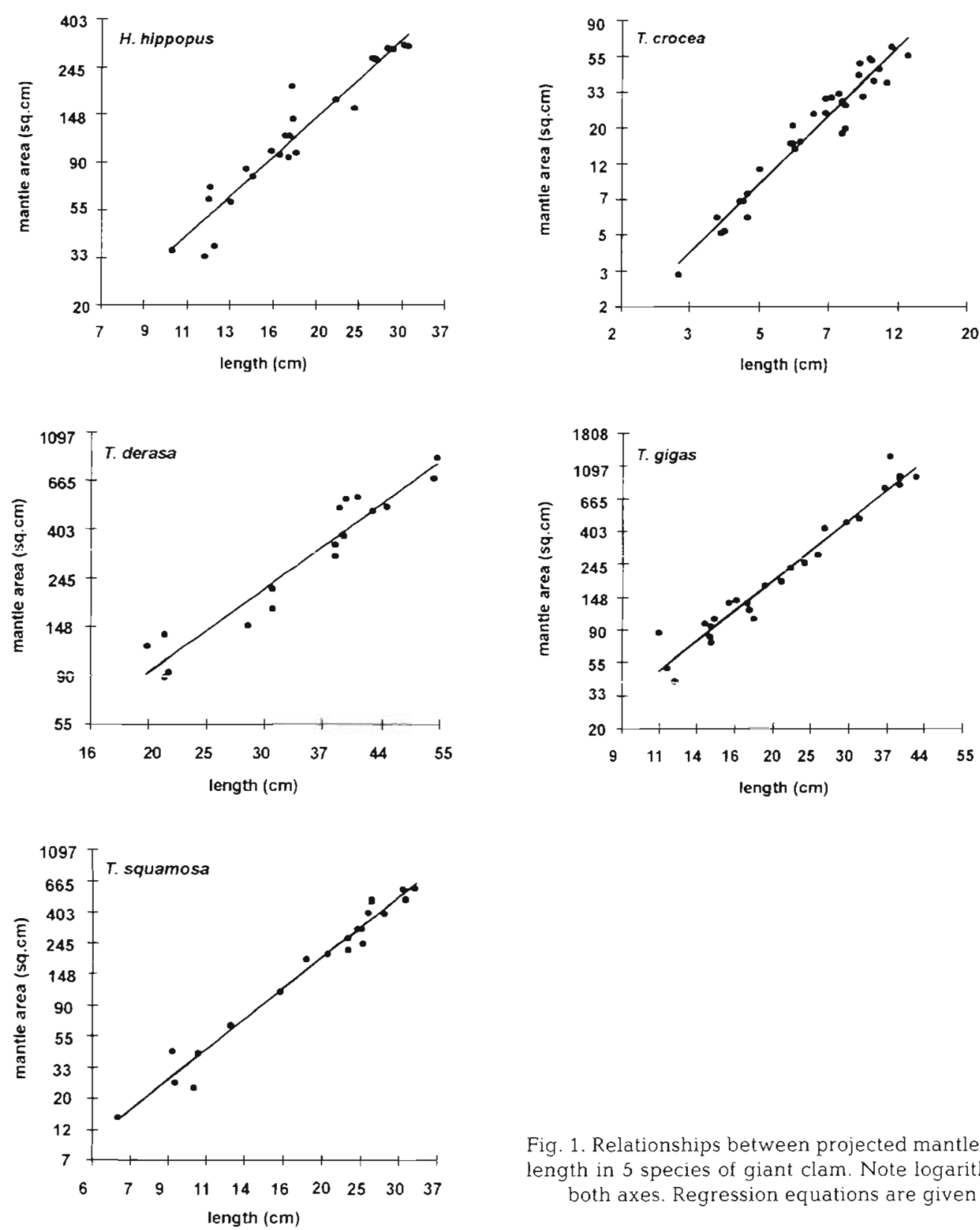

Fig. 1. Relationships between projected mantle area and shell length in 5 species of giant clam. Note logarithmic scales on both axes. Regression equations are given in Table 1

relatively small mantle areas, but expanding these rapidly with size. This trend is particularly marked in $T$. squamosa, which is ranked 4 th of the 5 species in terms of mantle area at $2 \mathrm{~cm}$ length, but by $30 \mathrm{~cm}$ length has a mantle more than twice as large as those of any other species.

\section{Numbers of zooxanthellae per clam}

All species show a logarithmic increase in the absolute numbers of zooxanthellae per clam with increasing shell length (Fig. 2). Slopes and intercepts of the

regression equations obtained, as well as calculated numbers of zooxanthellae present in clams of 2, 10 and $30 \mathrm{~cm}$ standard length, are shown in Table 2. The intercept or a values (zooxanthellae in clams of unit length) varied from a low of $0.5 \times 10^{6}$ cells in Tridacna squamosa to a maximum of $16.3 \times 10^{6}$ in $T$. derasa (despite the fact that this species has the smallest mantle area). The slopes, or $b$ values, which indicate rate of increase with shell length, varied from 1.54 to 2.76 but show the reverse sequence, the lowest value now occurring in $T$. derasa and the highest in $T$. squamosa. Slopes differed significantly except between $T$. crocea and $T$. derasa. 

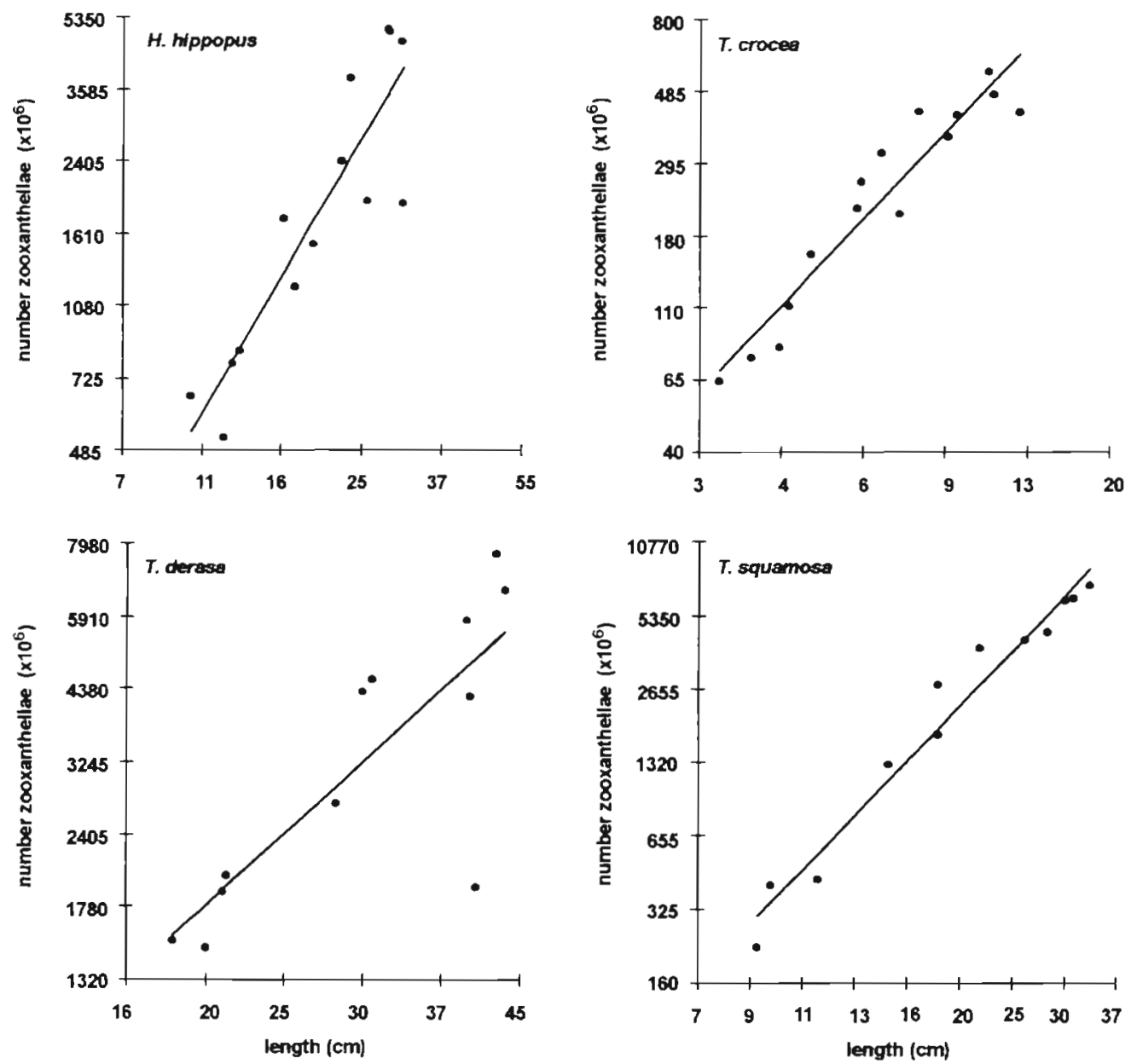

Fig. 2. Relationships between total numbers of zooxanthellae per clam and shell length in 4 species of giant clam. Note logarithmic scales on both axes. Regression equations for these species and Tridacna gigas (derived from Fitt et al. 1993) are given in Table 2

The net result is for marked size-related differences in the relative numbers of zooxanthellae between the various species. At a size of $2 \mathrm{~cm}$, for example, the numbers of zooxanthellae per clam differ by more than 10 -fold, from a maximum of $47 \times 10^{6}$ in Tridacna derasa, through $22 \times$ $10^{6}$ in $T$ crocea, $17 \times 10^{6}$ in Hippopus hippopus and $4.7 \times 10^{6}$ in $T$. gigas to a minimum of $3.4 \times 10^{6}$ in $T$. squamosa. However, this order has almost completely reversed by the time a size of $30 \mathrm{~cm}$ is reached, at which point $T$. squamosa has the largest zooxanthellae population $\left(5968 \times 10^{6}\right.$ cells $)$, followed by $T$ gigas, $H$. hippopus and then $T$. derasa at $3068 \times 10^{6}$ ( $T$ crocea does not attain this size, although projected values indicate an even lower number of zooxanthellae).

Numbers of zooxanthellae per gram dry body mass were greatest in the smallest clams of all species tested and decreased steadily with increasing clam size (Table 3, Fig. 3). The numbers of zooxanthellae present in clams of $1 \mathrm{~g}$ dry mass ( $\alpha$ val-

Table 2. Regression equations $\left(\mathrm{N}=a L^{b}\right)$ relating shell length $(\mathrm{L}, \mathrm{cm})$ and total numbers of zooxanthellae $\left(\mathrm{N} \times 10^{6}\right)$ in 5 giant clam species. Also shown are calculated zooxanthellae populations in clams of 2, 10 and $30 \mathrm{~cm}$ shell length. Data for Tridacna gigas adapted from Fitt et al. (1993) (note that $x$ and $y$ parameters were accidentally reversed in the equation as presented in that paper). $T$ crocea does not attain $30 \mathrm{~cm}$, hence this projected value is given in parentheses

\begin{tabular}{|lrrrrrrrr|}
\hline Species & $a$ & $b$ & $\mathrm{r}^{2}$ & $\mathrm{n}$ & \multicolumn{3}{c|}{$\begin{array}{c}10^{6} \text { zooxanthellae } \\
\text { at length }(\mathrm{cm})\end{array}$} \\
& & & & & & 2 & 10 & 30 \\
\hline Hippopus hippopus & 4.2 & 2.00 & 0.79 & 14 & 16.8 & 420 & 3780 \\
Tridacna crocea & 6.7 & 1.73 & 0.89 & 15 & 22.4 & 362 & $(2421)$ \\
T. derasa & 16.3 & 1.54 & 0.62 & 12 & 47.4 & 565 & 3068 \\
T. gigas & 0.81 & 2.54 & 0.96 & 22 & 4.7 & 282 & 4592 \\
T. squamosa & 0.50 & 2.76 & 0.96 & 12 & 3.4 & 288 & 5968 \\
\hline
\end{tabular}


Table 3. Regression equations $\left(\mathrm{N}=a \mathrm{M}^{b}\right)$ relating number of zooxanthellae $\left(\mathrm{N} \times 10^{6}\right)$ per gram dry flesh mass $(\mathrm{gdm})$ to dry flesh mass $(\mathrm{M}, \mathrm{g})$ in 5 species of giant clam. Data for Tridacna gigas are calculated from the regression equation relating length to zooxanthellae numbers given by Fitt et al. (1993) and the length to dry tissue mass relationship in Klumpp \& Griffiths (1994). Also shown are calculated densities of zooxanthellae $\mathrm{gdm}^{-1}$ for clams of 1,10 and $100 \mathrm{~g}$ dry flesh mass. $T$ crocea does not attain $100 \mathrm{~g}$, hence this value is given in parentheses

\begin{tabular}{|c|c|c|c|c|c|c|c|}
\hline \multirow[t]{2}{*}{ Species } & \multirow[t]{2}{*}{$a$} & \multirow[t]{2}{*}{$b$} & \multirow[t]{2}{*}{$r^{2}$} & \multirow[t]{2}{*}{$\mathrm{n}$} & \multicolumn{3}{|c|}{$\begin{array}{l}\text { Zooxanth. per gdm } \\
\text { at dry mass of }\end{array}$} \\
\hline & & & & & $1 \mathrm{~g}$ & $10 \mathrm{~g}$ & $100 \mathrm{~g}$ \\
\hline Hippopus hippopus & 337.6 & -0.471 & 0.77 & 14 & 338 & 114 & 39 \\
\hline Tridacna crocea & 334.3 & -0.872 & 0.92 & 15 & 334 & 45 & (6) \\
\hline I. derasa & 347.2 & -0.477 & 0.55 & 12 & 347 & 115 & 38 \\
\hline T. gigas & 177.8 & -0.244 & - & - & 178 & 101 & 58 \\
\hline T. squamosa & 232.1 & -0.309 & 0.74 & 12 & 232 & 113 & 56 \\
\hline
\end{tabular}

ues in Table 3) were similar between species, except for Tridacna squamosa and $T$. gigas, which had between $2 / 3$ and $1 / 2$ the numbers in the remaining species. Slopes of the regression lines ( $b$ values in Table 3 ) showed a considerabie range, with $T$. crocea exhibiting a much more pronounced size-related decline in zooxanthellae density than any other species. Of the remaining species, $T$. derasa and $H$. hippopus showed very similar trends, while $T$. squamosa and especially $T$. gigas had the slowest rates of decline in zooxanthellae density with increasing body weight.
These trends are clearly illustrated in the calculated zooxanthellae densities in clams of standard mass (Table 3). At $1 \mathrm{~g}$ mass, Tridacna gigas has by far the lowest cell density at $178 \times 10^{6}$ cells $\mathrm{g}^{-1}$, followed by $T$. squamosa at $232 \times 10^{6}$ cells $\mathrm{g}^{-1}$. The remaining species show values of 330 to $350 \times 10^{6}$ cells $\mathrm{g}^{-1}$. By $10 \mathrm{~g}$ mass, $T$. crocea has less than half the density of zooxanthellae $\left(45 \times 10^{6}\right)$ of any other species. At $100 \mathrm{~g}, T$. derasa and Hippopus hippopus have very similar zooxanthellae populations of 38 to $39 \times 10^{6} \mathrm{~g}^{-1}$, considerably less than the 56 and $58 \times 10^{6}$ cells $g^{-1}$ found in $T$. squamosa and $T$. gigas, respectively.

\section{Chlorophyll values}

Concentrations of chlorophyll, expressed as $\mu \mathrm{g}$ chl a and $c_{2}$ (the 2 dominant forms of chlorophyll in zooxantheilae; Jeffrey $\&$ Humphrey 1975 ) per $10^{6}$ zooxanthellae varied from a maximum of $6.25( \pm 1.3 \mathrm{SD}, \mathrm{n}=$ 12) in Tridacna crocea through $4.7( \pm 2.4, \mathrm{n}=10)$ in Hippopus hippopus and $4.6( \pm 0.9, \mathrm{n}=10)$ in $T$. squamosa to a minimum of $4.1( \pm 1.4, \mathrm{n}=9)$ in $T$. derasa. No size-related trends in chlorophyll concentration per zooxanthella could be detected.

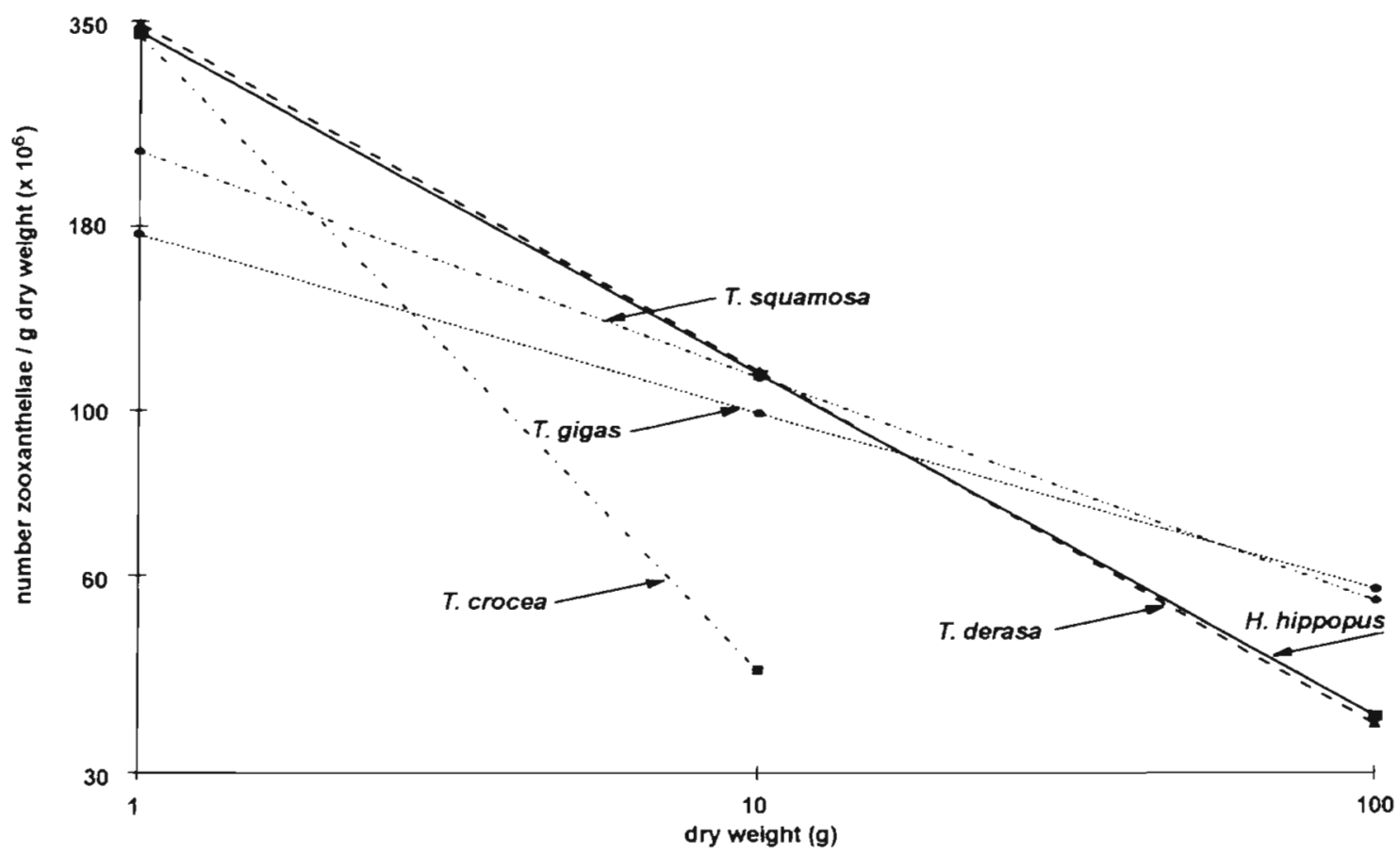

Fig. 3. Relationships between numbers of zooxanthellae per gram dry flesh weight and dry flesh weight in 5 species of giant clam. Note logarithmic scales on both axes. Numbers of zooxanthellae were calculated from the equations in Table 2 and length to dry flesh weight relationships from Klumpp \& Griffiths (1994), or in the case of Tridacna derasa, our own published data 


\section{DISCUSSION}

\section{Mantle areas}

All the clams studied showed a relative increase in projected mantle area per unit shell length as they increased in size (i.e. exponents of the regression equations exceed 2 -the value indicative of an isometric length to area relationship). In practice, this is evidenced by a relative increase in shell breadth and of mantle width with increasing size. The mantle may also become more convoluted in larger specimens. Such 3-dimensional changes in mantle morphology may influence photosynthetic efficiency, but this factor was not considered here.

Of particular significance is the very rapid rate of increase in relative mantle area in Tridacna squamosa. The enlarged scutes on the shell of this species may assist in supporting the lateral projections of its mantle, which at large size may cover twice the area of that in any other species. $T$ crocea is also notable in that it exhibits the reverse trend, having a relatively large mantle early in life, but a low $b$ value close to 2 , so that the mantle area barely keeps pace with increasing shell length at larger sizes. T. derasa is also remarkable in its consistently low mantle area throughout life.

\section{Number of zooxanthellae}

As would be expected, our results show logarithmic increases in total zooxanthellae numbers with increasing clam length in all species studied. The equations relating zooxanthellae numbers to shell length in Hippopus hippopus, Tridacna crocea and $T$ derasa all have exponent values lower than those relating mantle area to length (Tables $1 \& 2$ ). This indicates a decline in zooxanthellae density per unit mantle area in larger clams. $T$. squamosa and $T$. gigas show the reverse trend and hence have greater densities of zooxanthellae per unit mantle area at larger size. The results of these differing trends are best seen in the figures for total zooxanthellae numbers. These clearly distinguish 2 groups of species: one (H. hippopus, T. crocea and T. derasa) with relatively high zooxanthellae populations early in life and relatively low ones at larger size, and the other ( $T$. gigas and $T$. squamosa) which initially harbours far fewer symbionts, but ultimately develops the largest populations.

Calculations of zooxanthellae numbers per gram flesh mass (Table 3) show that such densities decline with increasing clam size in all species sampled. This is to be expected, since the zooxanthellae are almost all confined to the surface layers of the mantle, which, relative to the body as a whole, is essentially 2 -dimen- sional. Clam weight is, however, related to volume, so is a cubic function with a length exponent between 3.2 and 3.5 (see Klumpp \& Griffiths 1994). While such relationships are valid for clams $>1 \mathrm{~cm}$ in length, it should be noted that the symbiotic relationship between clams and their zooxanthellae only commences after metamorphosis - the juveniles acquiring their zooxanthellae through filter-feeding activities (Lucas 1994). Densities of zooxanthellae would hence be low in newly metamorphosed juveniles, as has been shown in Tridacna gigas by Fitt et al. (1993).

Absolute zooxanthellae densities per gram flesh mass were fairly consistent between species at small size (Table 3), but declined much more rapidly in Tridacna crocea than in the remaining species. Those species with low initial values ( $T$. gigas, $T$. squamosa) again achieve the highest densities of symbionts by a weight of $100 \mathrm{~g}$.

\section{Chlorophyll concentrations}

Measurements of chlorophyll content per $10^{6}$ zooxanthellae indicate little interspecific variation in chlorophyll content, other than an elevated value for Tridacna crocea. Chlorophyll concentrations obtained here are somewhat higher than those reported for $T$. gigas by Belda et al. (1993), who give values of between about 1 and $3 \mathrm{pg}$ zooxanthella ${ }^{-1}$ (= $\mu \mathrm{g}$ zooxanthellae $10^{-6}$ ). Their measurements were, however, expressed as chl a content only, whereas we estimated both chl a and $c_{2}$. Chl $c_{2}$ comprises approximately $30 \%$ of total chlorophyll and when this is taken into account there is close correlation between the 2 data sets. Any differences might in any event not represent consistent interspecific patterns, but could be the result of environmental conditions, since it has been established that chlorophyll content per zooxanthella is sensitive to factors such as the nutrient regime (Belda et al. 1993).

\section{Implications for nutrition and growth}

Of the parameters measured here one might expect numbers of zooxanthellae per gram of clam tissue weight (Fig. 3) to give the best indication of the relative contribution of phototrophic production to host requirements. These data clearly show a rapid decline in weight-specific zooxanthellae density with size in Tridacna crocea. This is a direct result of the rapidly increasing mass at length in this species (for length/weight relationships see Klumpp \& Griffiths 1994, Klumpp \& Lucas 1994). This results in $T$. crocea having a flesh weight of more than $3 x$ that of any other species by the time it attains $100 \mathrm{~mm}$ shell length. Weight-specific variations in zooxanthellae 
numbers are less marked amongst the remaining species, although $T$. squamosa and $T$. gigas do have considerably more zooxanthellae $\mathrm{g}^{-1}$ than $T$. derasa or Hippopus hippopus at larger sizes.

Of course, zooxanthellae number is not the sole variable determining photosynthetic production, which may also be influenced by such factors as location of the zooxanthellae within the tissues, mantle area and clam posture, etc., as well as environmental factors such as water depth, shading, etc. Indeed, direct measurements of photosynthetic rate made by Klumpp \& Griffiths (1994) indicate that Tridacna crocea is able to maintain a photosynthetic rate comparable with other species, and exceeding that in Hippopus hippopus, up to a weight of $10 \mathrm{~g}$. There is, however, a progressive decline in performance with size, so that if $T$. crocea were to attain $100 \mathrm{~g}$, its photosynthetic rate would have declined to about half that of other clam species (Klumpp \& Griffiths 1994; their Table 4). The reason why $T$. crocea is able to maintain a better than expected photosynthetic rate, relative to species with more zooxanthellae, could be a function of its higher chlorophyil content pei zooxanthella, relalively large mantle area (Table 1), or of the placement of zooxanthellae within the mantle for optimal illumination.

Of the remaining species, Tridacna gigas and $T$. squamosa start with relatively low zooxanthellae densities, but because of low weight-specific rates of decline, have the highest densities at sizes over $10 \mathrm{~g}$ flesh mass. This is reflected in their high relative photosynthetic rates (Klumpp \& Griffiths 1994; their Table 4). T. derasa and Hippopus hippopus appear to have relatively low weight-specific zooxanthellae populations at large size and indeed have correspondingly low absolute photosynthetic rates (Klumpp \& Griffiths 1994, Klumpp \& Lucas 1994). Surprisingly, however, both species rank amongst the faster-growing of tridacnids. In the case of $H$. hippopus this can largely be attributed to a very low rate of respiration and an unusually high rate of absorption of ingested food (Klumpp \& Griffiths 1994). However, in T. derasa both the photosynthetic rate and CZAR (contribution of zooxanthellae to animal respiration) values are low (Klumpp \& Lucas 1994), as indeed is the clearance rate.

The above interspecific comparisons are based on clams that were either reared in culture, or transferred to standard laboratory conditions from diverse natural habitats weeks or months prior to experimentation (the exception being the few mantle areas taken from very large individuals in the field). It is recognised that in nature clams may adjust their mantle area, number of zooxanthellae, or chlorophyll concentration per zooxanthella (see above) in response to ambient conditions, confounding any analysis. However, based on our laboratory-conditioned animals it would appear that the small size attained by Tridacna crocea can be associated with a rapid decline in zooxanthellae numbers relative to body weight in that species, which in turn is paralleled by a rapidly declining weightspecific photosynthetic rate (Klumpp \& Griffiths 1994). The boring habits of this species may also place a constraint on the terminal size that can be attained. The exceptionally rapid growth rate and large size attained by $T$. gigas may partly be a function of a low weightspecific decline in zooxanthellae density (which becomes particularly significant at very large body size). At small size, however, growth appears to be maintained by an exceptionally rapid rate of filter feeding (Klumpp \& Griffiths 1994, their Table 5). All indications suggest that $T$. squamosa has high concentrations of zooxanthellae and fast photosynthetic rates at large size, yet this species shows a relatively poor growth performance relative to $T$. gigas (Klumpp \& Griffiths 1994). The reasons for this are obscure, but could include earlier maturity and higher reproductive output than occurs in $T$. gigas. The comparative measures of reproductive output in clam species that are required to nake suchl calcuidiluns are nut availdble and remain a promising area for future investigation.

Acknowledgements. We are indebted to David McKinnon and Sheryl Fitzpatrick of AIMS for their assistance with experimental procedures, to David Yellowlees for demonstrating his procedure for the extraction of zooxanthellae and to Kim Navin for use of his digitizer. David Glassom of UCT assisted with the statistical analyses. C.L.G. is grateful to the University of Cape Town for granting him sabbatical leave in order to undertake this study and to the Foundation for Research Development and Vera Davie Study and Travel Bursary Fund for financial support during his visit to Australia. This is AIMS Contribution No. 808.

\section{LITERATURE CITED}

Belda CA, Lucas JS, Yellowlees D (1993) Nutrient limitation in the giant clam-zooxanthellae symbiosis: effects of nutrient supplements on growth of the symbiotic partners. Mar Biol 177:655-664

Fisher CR, Fitt WK, Trench RK (1.985) Photosynthesis and respiration in Tridacna gigas as a function of irradiance and size. Biol Bull 169:230-245

Fitt WK (1993) Nutrition of giant clams. In: Fitt WK (ed) Biology and mariculture of giant clams. ACIAR Proceedings No. 47. Australian Centre for International Agricultural Research, Canberra, p 31-40

Fitt WK, Fisher CR, Trench RK (1986) Contribution of the symbiotic dinoflagellate Symbiodinjum microadriaticum to the nutrition, growth and survival of larval and juvenile tridacnid clams. Aquaculture 55:5-22

Fitt WK, Rees TAV, Braley RD, Lucas JS, Yellowlees D (1993) Nitrogen flux in giant clams: size-dependency and relationship to zooxanthellae density and clam biomass in the uptake of dissolved inorganic nitrogen. Mar Biol 117; 381-386

Jeffrey SW, Humphrey GF (1975) New spectrophotometric 
equations for determining chlorophylls $a, b, c_{1}$ and $c_{2}$ in higher plants, algae, and natural phytoplankton. Chem Physiol Pflanzen (BPP) 167:191-194

Klumpp DW, Bayne BL, Hawkins AJS (1992) Nutrition of the giant clam Tridacna gigas (L.). I. Contribution of filter feeding and photosynthesis to respiration and growth. J Exp Mar Biol Ecol 155:105-122

Klumpp DW, Griffiths CL (1994) Contributions of phototrophic and heterotrophic nutrition to the metabolic and growth requirements of four species of giant clam (Tridacnidae). Mar Ecol Prog Ser 115:103-115

Klumpp DW, Lucas JS (1994) Nutritional ecology of the giant clams Tridacna tevoroa and $T$ derasa from Tonga: influence of light on filter-feeding and photosynthesis. Mar Ecol Prog Ser 107:147-156

Ledua E, Manu N, Bradley RD (1993) Distribution habitat and culture of the recently described giant clam Tridacna tevoroa in Fiji and Tonga. In: Fitt WK (ed) Biology and mariculture of giant clams. ACIAR Proceedings No. 47. Australian Centre for International Agricultural Research, Canberra, p 147-153

This article was submitted to the editor
Lucas JS (1988) Giant clams: description, distribution and life history. In: Copland JW, Lucas JS (eds) Giant clams in Asia and the Pacific. ACIAR Monograph No. 9, Australian Centre for International Agricultural Research, Canberra, $p$ 21-32

Lucas JS (1994) The biology, exploitation, and mariculture of giant clams (Tridacnidae). Rev Fish Sci 2:181-223

Mingoa SM (1988) Photoadaptation in juvenile Tridacna gigas. In: Copland JW, Lucas JS (eds) Giant clams in Asia and the Pacific. ACIAR Monograph No. 9, Australian Centre for International Agricultural Research, Canberra, p $145-150$

SAS (1985) SAS user's guide: statistics, Version 5 edn. SAS Institute Inc, Cary, NC, p 448-453

Trench RK. Wethey DS, Porter JW (1981) Observations on the symbiosis with zooxanthellae amongst the Tridacnidae (Mollusca, Bivalvia). Biol Bull 161:180-198

Yonge CM (1936) Mode of life, feeding, digestion and symbiosis with zooxanthellae in the Tridacnidae. Scient Rep Gt Barrier Reef Exped 1:283-321

Zar (1984) Biostatistical analysis. Prentice-Hall, New Jersey

Manuscript first received: April 3, 1995

Revised version accepted: January 3, 1996 